\title{
Systematicity of the Criminal Legislation of Russia: Methodology Issues
}

\author{
Artur G. Bezverkhov and Yuriy S. Norvartyan* \\ Samara National Research University \\ 34 Moskovskoye Shosse, Samara, 443086, Russia
}

Received 29.01.2019, received in revised form 14.02.2019, accepted 06.03.2019

\begin{abstract}
The article explores the possibilities and limits of using a system approach in criminal law matter, its interaction with other methodological tools. It is shown that a systemic structure of the criminal legislation of Russia is focused on streamlining legal material, ensuring its consistency and completeness of regulation of public relations, and excluding duplication and gaps in the criminal law. It was determined that systematicity is a phenomenon, both intra-industry and inter-industry. Criminal law is systematically connected with many other sectors - constitutional, civil, labour, financial, environmental law, criminal executive, procedural law, etc. At the same time, criminal illegality is determined by criminal law, taking into account the effect of those legal regulations of various sectoral nature that regulate social relations violated by a criminal act.
\end{abstract}

Keywords: system approach, systematicity, system relations, criminal law system, criminal law system, systematic interpretation, General and Special parts of criminal law.

Research area: law.

Citation: Bezverkhov, A.G., Norvartyan, Yu.S. Systematicity of the criminal legislation of Russia: methodology issues (2019). J. Sib. Fed. Univ. Humanit. soc. sci., 12(3), 325-342. DOI: $10.17516 / 1997-1370-0397$.

Statement of the problem. Any theoretical and applied research distinguishes the peculiarities of the subject of knowledge and the methods used in the course of creative activity. Two necessary components of scientific research, a subject and a method, are naturally connected and are in constant interaction with each other. Each subject requires the use of methods consistent with it. In this sense, the subject involves a certain research methodology; the specificity of the method derives from the characteristics of the subject. Meanwhile, the method forms the subject. At the same

(C) Siberian Federal University. All rights reserved

* Corresponding author E-mail address: norvartyan@yandex.ru

ORCID: 0000-0002-8872-4497 (Norvartyan)

This work is licensed under a Creative Commons Attribution-NonCommercial 4.0 International License (CC BY-NC 4.0). 
time, the success of theoretical and applied research largely depends on the perfection of the chosen method. The value of the method in scientific research is so great that one can, without exaggeration, call it a key component of the process of searching for truth and obtaining scientific knowledge. I.P. Pavlov wrote, "a method is the very first, basic thing. All the seriousness of the study depends on the method and the way of action. It's all about the good method. With a good method, even a person who is not very talented can do a lot. And with a bad method, the most ingenious person will work for nothing and will not obtain valuable, accurate data... The method holds the fate of the research." (Pavlov, 1952: 26, 28).

In a number of components of the methodology - the whole diversity of principles, methods, techniques, approaches, operations and procedures that make up the method of knowledge - systematicity should be considered as one of the varieties of the methodological approach. The concept of a systematic approach has now begun to play a universal, methodological role. Its scientific importance in the modern process of knowledge has grown so much that it is now difficult to imagine an intellectual search without a system basis. A systematic approach is one of the modern ways of obtaining and implementing scientific knowledge. Its application in scientific research allows us to cover all the aspects and moments of already known phenomena and processes of the world around us, thus making the study of the subject of knowledge described in all its connections, relationships and mediations very thorough and more productive than the traditional one. The systematic research is focused on building a model of holistic perception and comprehensive understanding of reality, and, accordingly, has the ultimate goal of creating a picture of the world at the deepest level of interdisciplinary understanding, thus it may require joint efforts of specialists from several different disciplines.

Essence of the systematic approach. From the point of view of the Russian language, the words "approach", "to approach" mean: access; a trick; discovering one's attitude towards someone; starting doing something with a certain point of view. The methodology has not yet developed a common understanding of the methodological approach. In the study of the method, the general concept of the approach is used in a wide variety of contexts. Thus, the methodological approach is considered as an ideological position, from which the subject of research is considered, as a principle or a set of principles that orient the research and determine their overall strategy, mainstream direction, or as the use of a certain set of methods and procedures of knowledge (Blauberg, Iudin, 1973: 74). According to V.A. Kozlov, the approach 
designates the main way, a strategy of solving the assigned task, and by "outlining the basic view of the object's study it determines only the general peculiarity of one or another method. The approach is specified in the principles inherent in the corresponding method" (Kozlov, 1989: 88). Finally, within the framework of distinguishing between the method of science and the method of scientific research, N.N. Tarasov writes that the methodological approach relates to the method of scientific research, and to not the method of science and, therefore, cannot be included in the method of science. In connection with the above, the author argues that "the methodological approach, representing the synthesis of the most fundamental characteristics of the method of science and being a form of its "external expression", sets the fundamental framework for the adequate application of the relevant elements of the method in scientific research... Regarding the method of science, the methodological approach is its expression in the form of principal categories, basic concepts and research frameworks... As for the method of a certain research, the methodological approach acts as its constructive element..." (Tarasov, 2001: 45-46).

As can be seen, the methodological approach is often identified with such components of the methodology as a principle, a method, a procedure of knowledge, or is included in the scope of one or another type of a methodological analysis. Meanwhile, in the study of the method of knowledge, the methodological approach should rather be understood as an independent methodological component that is equal among other means and methods of the scientific analysis. It is necessary to agree with V.P. Kuzmin, that any methodological tool - an approach, a principle, a type of analysis - is a relatively independent part of the methodology (Kuzmin, 1980: 50). Hence, the system approach as a fundamental concept standing in the same row with other methodological approaches should be considered in the strict sense as one of the relatively independent components of the methodology.

It is well known that the structure of scientific methodology is diverse and allows us to distinguish the following three types of methods of knowledge: a) universal (philosophical), b) general-scientific (equipping all or most of the areas of knowledge) and c) particular-scientific (specific). In a series of three levels of methodological tools, the systems approach has a general scientific character of research and can find effective application in various fields of scientific knowledge. Such a conclusion can be made if we take into account the distinctive feature of a comprehensive study, which is expressed in a comprehensive study of the subject of knowledge taken in all its aspects - interactions, connections and mediations. It is assumed that each 
scientific discipline considers its object from one point of view that is present only in it. On the other hand, the assertion of the existence of not only intra-branch, but also inter-branch consistency is not groundless (Osipov, 1989: 21). In this connection, a statement that the knowledge of such phenomena and processes that are recognized as the object of at least two different sciences, or each side of which is studied by a particular science, requires a systematic approach, has received universal acceptance. As A.M. Vasil'ev noted, it is impossible to reveal the essence and specifics of any social phenomenon without clarifying its relations with all aspects of public life, without clarifying the laws of interaction of all parts of society and its movement as a whole (Osipov, 1989: 21).

A question of identifying the essence of the system approach as a specific way of the attitude of a person to the world is very difficult. We face great difficulties in trying to give a detailed definition of this widely used scientific concept. It is equally difficult to give it a precise meaning. After all, the objects of the systematic research are those phenomena of reality that constitute systems. A system (from the Greek Systěma - a whole made up of parts) refers to an ordered set of elements that form a certain integrity (unity). The experience of the system research shows that the system is unthinkable without the parts forming it, since it is the result of the interrelation between them. In general, there is nothing but its parts and their interaction (Afanas'ev, 1981: 248). A distinctive feature of systematicity is its special integrative character that ensures the internal and external integrity of system education. Integrity is expressed in the presence of a system of qualities and properties that are absent in its constituent elements. Integrity gives the system decisive importance in relation to its elements that are directly involved in the formation of its systemic qualities. Affecting its elements, the system transforms them according to its own nature. As a result, the original ingredients change losing the properties that they had before entering the system and acquiring a new quality. Moreover, there is dependence of each element of the system on its place in the system education. System objects usually do not allow the separation of elements. The system rejects the opposing element.

Equally, the notion of "systematicity" in criminal law is multi-valued, since it has a different understanding in various contexts. In the legislative aspect, "systematicity" is one of the main requirements for criminal law-making and principles of the criminal legislation. On the part of law enforcement, "systematicity" is one of the ways to clarify the meaning and content of the criminal law by comparing it with other criminal law norms or norms of a different branch affiliation. From a scientific and philosophical 
point of view, "systematicity" can be viewed as one of the types of the methodological approach to the study of criminal law phenomena, which is based on an understanding of the relevant branch of law and legislation as an integral system.

The system approach arose in the middle of the twentieth century and almost immediately received universal recognition in Russian jurisprudence. According to D.A. Kerimov, the use of the system approach to the knowledge of legal research allows one to reveal the "internal unity of law, the organic interrelation and the harmonious interaction of the parts, its components" (Kerimov, 1972: 274). "A researcher will succeed only in that case," L.S. Iavich wrote, "when he studies the norms and institutions of law taking into account the entire legal system, its branches and other subdivisions" (Iavich, 1972: 127). The system approach is opposed to all the controversial, unsystematic, total. He focuses on the order of combining phenomena and processes into the new holistic education. Therefore, the system approach is intended to ensure the comprehension of reality from the formal side through its formalization. In this regard, it was noted that the practical significance of the system approach is that it streamlines the train of thought of the researcher and thereby saves his efforts. Thanks to the methodological approaches, we learn why, where and what we should look for, and thanks to the system approach - how to do it (Osipov, 1989: 13).

Systematicity in criminal law. Systematicity is also expressed in criminal law as a multidimensional phenomenon - a branch of law, a branch of legislation, a branch of science, an academic discipline. The system approach here is determined by the understanding of criminal law in any of the above meanings as holistic systemic education, which is composed of a number of parts and many components. Criminal law has a multi-level structure. As a branch of legislation, it is part of a system of another, higher level (system of legislation), and its parts and more divisional components (sections, chapters, articles), in turn, act as independent systems of a lower order. The purpose of the systemic structure of the criminal law is streamlining the legal material, ensuring its consistency and completeness of regulation of public relations, excluding repetitions and gaps in the criminal law.

The subjects of protection of the criminal law are the most important social relations, the absolute majority of which are of a systemic nature. Also, the method of the criminal law as a branch of law represents, in its most general form, a system of legal means, including prohibitions, positive obligations, permissions and incentives. In the theory of the criminal law and legislation, there is a system approach to defining a crime, which can conditionally be called substantive. The elemental structure of 
crime should also be noted. In the fight against crime, the criminal law uses a system of coercive measures of a criminal law nature. The formation of the conceptual apparatus of the criminal law, which is not a simple set of terms, but a system of consistent and interrelated concepts and categories, is based on the system approach.

It is true that science is seeking something repetitive; it is seeking generalizations; it has little interest in facts that are reliable only for a particular experiment performed on a particular day. Science reveals the laws that make up its subject. The subjects of the system research of the criminal law phenomena are two types of sustainable relations (internal and external) that ensure stability of the criminal law and legislation. The first are formed between different parts and elements of the criminal legal system. Any system means not only a set of parts and elements, but assumes that the system components are not isolated from each other, but are in the process of interaction. Stable interconnection, in which elements of a systemic whole are interconnected, is one of the distinguishing features of systematicity. Interaction between the parts of a systemic whole is expressed in some form of their subordination in relation to each other, which orders the elements in the structural series of the system. Thus, the systemic order in the criminal law is achieved by combining regulatory prescriptions for various reasons into certain groups, as well as their location in a certain sequence relative to each other. This type of relations is formed in the criminal law between: (1) the regulations of its General and Special Parts; (2) regulations contained in its various sections; (3) regulations in different chapters of the same section; (4) regulations provided for in different articles of one chapter; (5) regulations contained in one article. As a result, all regulatory prescriptions occupy corresponding places in relation to the criminal law as a whole, its parts, sections, chapters and articles. In this regard, determination of the meaning and content of regulations depends on the place that they have in the criminal law.

The second type of relations operates between the criminal law and the subject area of reality - the legal system as a whole. If such relations are sustainable, then the criminal law is considered as a component of a more complex legal system. As you can see, systematicity is a phenomenon, both intra-industry and inter-industry. The criminal law is located in a complex interdisciplinary network of relations and dependencies. There is a particularly obvious connection of this industry with those industry branches that constitute a single unit in the fight against crime and other antisocial manifestations - criminal procedure, criminal executive and administrative law. However, this does not exhaust plentifulness of interdisciplinary cooperation 
involving criminal law. The latter is systematically connected with many other sectors constitutional, civil, labor, financial, environmental law, etc. The criminal legislation is based on the Constitution of the Russian Federation and the generally recognized principles and norms of international law, is consistent with other industry branches and is provided for by a criminal procedure and criminal enforcement legislation. Criminal wrongfulness is often determined by the criminal law in close connection with the regulations of a different industry affiliation. Changing the content of the latter with the immutability of the text of the criminal law may lead to a narrowing or, conversely, to the expansion of the scope of the criminal law. Therefore, consistency remains the basic requirement in the sphere of inter-sectoral systemic interaction of legal norms.

Criminal legal science is in a diverse relationship with other legal sciences and branches of knowledge. Such interaction of the criminal law with other legal and nonlegal sciences has the many-sided nature of law as its basis, i.e. stable and necessary interrelation of legal "parties" ("edges") both with each other and with other social phenomena. In the latter case, a systematic approach to the study of the criminal law makes it possible to explain its economic, political, ideological and moral foundations and significance. Thus, A.A. Gercenzon wrote that the sociological aspect of the study of the problems of the criminal law makes it possible to fill the real content of the criminal law, concepts and institutions of the criminal law (Gercenzon, 1970: 39). L.I. Spiridonov emphasized the importance of considering the criminal law institutions and norms in their socio-economic conditionality, in conjunction with other social institutions (economics, politics, culture), since it contributes to the enrichment of knowledge about the criminal law, and it raises them to a qualitatively new level (Spiridonov, 1986: 19). A.N. Ignatov summarizes the above statement that "many modern problems in the fight against crime can only be solved on the basis of a comprehensive study of issues using scientific developments in various branches of knowledge" (Ignatov, Krasikov, 1998: 18).

The correlation of systematicity and complexity is another methodological problem. In some cases, the concept of systematicity is widely understood and even includes in its scope the category of complexity. Such an understanding has the following rather widespread theory of systems theory in science as its logical basis: every system is part of a system of another, higher level, and its elements and subsystems, in turn, are considered as independent systems of a lower order. Hence, it becomes possible to define the system as an organized set of means to achieve a common goal, as an 
organizational or composite whole, a set or a combination of elements or parts that form a single complex or a single whole, or as a complex of components interacting in one way or another (Kliland, King, 1974: 32). In this case, the system approach is understood as a comprehensive and multidimensional approach that us becoming an increasingly "integrated methodological tool" (Kuzmin, 1980: 52). In terms of the corresponding direction, the complexity can be interpreted through the concept of systematicity: a complex as a large "mixed" system, in which several whole systems of a lower order or their elements are integrated. In this regard, supporters of the direction under consideration understand an integrated approach, according to which in every rather complex phenomenon it is necessary to explore all its aspects (for example, in a social phenomenon - economic, social, ideological, psychological, organizational, etc.). In this sense, systematicity acquires a new aspect: not only organizational completeness and integrity, but also the fullness of coverage of all aspects of the phenomenon. This is also an integrity analysis, but from a new perspective. This particular aspect of the analysis of systematicity is defined as the complexity itself (Stefanov, et al., 1975: 184). To the greatest extent, the essence of the above understanding of the phenomenon of systematicity is reflected in the formula "an integrated system approach" (Kuzmin, 1980: 49). Indeed, the systemic and integrated approaches are interrelated in the sense that they both provide a holistic perception of reality, a single vision of the picture of the world around us. Consequently, both complexity and system are formed under the influence of integration processes. Let us recall that integration (from the Latin integercomplete, full) is a process that has, as a result, integrity, connection or restoration of unity. It is integration, as a natural unification of the whole into a coordinated activity of the whole, that precludes contradiction of the complex and systemic approaches and acts as the basis for their interconnection.

In accordance with another view, the integrated approach acts as an independent method, a new methodological component. The first attempt to consider the complexity as a special method of scientific research was undertaken by B.M. Kedrov in the early 80's. In his article "On the Modern Classification of Sciences (Major Trends in Its Evolution)", this scientist rightly focused on the need to "develop, or rather, create and substantiate a special, complex method of knowledge, an integrated approach to the object being studied as an integral element of the dialectical method in its modern understanding" (Kedrov, 1980: 100). In his other work, B.M. Kedrov wrote, "what is called by the interaction of sciences in the study of the same object that is common to them, can be defined in other words as an integrated research method, an integrated 
approach to the object being studied". As you can see, supporters of this direction talk about the complex "mainly in cases when the inter-sectoral integration is being carried out to achieve a common goal" (Stefanov, et al., 1975: 38), when a special synthesis of research results of various scientific disciplines occurs when the principle of scientific understanding is an interdisciplinary analysis of the object of knowledge.

Hence, it is rightly noted that the integrated and system approaches, although interrelated, but are not identical, and they should not be confused. Along with the existence of similarities between the system and complex approaches, there is difference between them, which, in general, does not allow for the integration of complexity to be referred to a kind of systematicity. In this case, the complex method of cognition is recognized for its methodological value only akin to the system approach and is not "absorbed" by the latter. We should agree with V.G. Afanas'ev that the concepts of "a complex" and "a system" (and, accordingly, "an integrated approach" and "a system approach") are close in the sense that both are a definite set of components and elements that specifically interact with each other. When it comes to some kind of integrity, the concepts of "a complex" and "a system" are used as synonyms. However, there are certain differences between these concepts (Afanas'ev, 1981: 249). As rightly noted in science, the understanding of a system as a complex of components interacting in one way or another is too broad, because it includes various kinds of conglomerates, mixtures, the properties of which are reduced to a simple sum of the properties of the components (Afanas'ev, 1981: 249).

The existence of certain complexes in the world is determined by the action of necessary and stable essential connections between various sides of integrated heterogeneous phenomena and processes - complex laws. The main reason for the existence of a connection between heterogeneous phenomena and processes should be seen in the fact that during its formation, the full "energy" of the phenomena and processes that make up the complex is somewhat reduced. Therefore, the "energy" of complex education is always less than the total "energy" of isolated phenomena and processes. In this case, the relation becomes stable, and there is the existence and functioning of the complex. The presence of such a relation is fraught with negative consequences for the ingredients in the complex: the functioning of one of them can be disturbed even when the functioning of the other becomes disordered. Thus, criminal wrongfulness is often determined by the criminal law in close connection with the regulations of a different industry affiliation. Changing the content of the latter with the immutability of the text of the criminal law itself may lead to a narrowing or, 
conversely, to an expansion of the scope of the criminal law prohibitions. Collisions (gaps) in the general legal (sectoral) regulation of relations that are subject to the criminal law protection may entail either the inaction of the criminal law norm or unjustified government coercion.

An integrated approach, requiring consideration of the entire set of interactions between all sorts of sides of a problem, implies a multivariate solution. Thus, even if to reduce the set of these options to some observable number abstracting from all "unimportant details", even then it is impossible to be confident in the logical and correct solution of the complex problem. The correct solution of the latter requires the selection of the most optimal available options. However, the integrated approach does not determine which of the available alternatives is the best. The process of finding the optimal solution, the choice of the best alternative is always beyond the scope of the integrated approach.

Finally, complex generalization leads to certain "coarsening" of the object of knowledge and, accordingly, to the erasure of a number of nuances and shades that are peculiar to it and are very significant from the point of view of the special sciences. As V.O. Tenenbaum notes, in the categories of the theory of state and law, the state and law act precisely as "themselves", as such, whereas in the categories and concepts of other sciences - as "others", due to which the transitions of the sides and edges of the state and law into economics, politics, culture, morality, etc., their interdependencies and connections occur (Tenenbaum, 1971: 16). It also seems obvious that a comprehensive study of, for example, criminal behaviour taking into account the influence of many factors of different nature: legal, historical, cultural, national-traditional, political, moral-ethical, natural-climatic, etc., is fraught with a "loss" of some legal properties of socially dangerous acts that are essential for the criminal law specialists, since, to a certain extent, they ignore a thorough and detailed analysis of the elements of a crime.

The interaction between the parts of a systemic whole is expressed in different forms of their subordination in relation to each other, which organizes the elements in the structure of the system. The system order consists in observing the established rules for combining the elements of the system for certain characteristics into certain groups, as well as their location in a specific sequence with respect to each other: all elements occupy corresponding places with respect to the whole and other parts. Therefore, a systematic approach is intended to ensure the comprehension of reality from the formal side, through its formalization. In this regard, it was rightly noted: 
"Through an integrated approach, we learn why, where and what we should look for, and thanks to the system approach - how to do it."

The difference in the approaches under consideration is also found in the features of the objects of the complex and systematic research. If the system approach is a way to study the objects-systems, then the complexity consists in the knowledge of objects-complexes. System objects usually do not allow the separation of elements. As noted, in isolation from the whole, the elements of organic systems not only lose a number of properties, but cannot exist at all. Under the complex, in the context of the system approach, we should rather understand a group (association) of integral systems or their elements, jointly (simultaneously and concertedly) acting and thus mutually influencing each other. Phenomena or processes of the surrounding reality that form a complex and influence each other, do not lose their autonomy, independence, i.e. aspiration for orderliness and obtaining their own structure. Consequently, the components of the complex can act both independently (autonomously) and jointly. They retain their universal features, integral (system) properties and remain external to each other, so to speak, a whole integrated with another whole into a complex union. Thus, economic interrelations, taking the legal form, do not become non-economic relations in this connection. Similarly, the law regulating relations in the economic sphere, does not lose its normative properties and does not become an economic go, not giving in to economic assessments in general. The existing relations between the components of the complex play a certain role in the functioning of the latter (for they determine the occurrence of new properties and qualities in them), but they are never of a hierarchical, coordinated nature. Thus, if the systems approach focuses on the order of combining phenomena and processes into a new holistic entity, then the integrated approach focuses on combining autonomous objects that, while simultaneously and consistently functioning, form a single whole.

Criminal law in the inter-sectoral interaction. It has long been noted that "the current trend in improving the criminal law is its increasingly close relation with the norms of other branches of law" (Kudriavtsev, 1999: 160) and that it is a comprehensive analysis of the relations of criminal law with other branches that provides a sufficiently deep identification of the nature of the criminal law norms (Alekseev, 1971: 43). It is also obvious that the criminal law is not equally strongly connected with other branches, and this relation is very diverse. Meanwhile, in the criminal law theory, when characterizing the interaction of the criminal law with other sectors of legislation, attention is usually focused on one kind of inter-sectoral relationship. 
The question of the interaction of criminal law and other sectors is solved, mainly taking into account the systemic nature of inter-sectoral relations. As V.P. Malkov rightly asserts: "The norms of criminal law are closely interrelated with the norms of other branches of law and act systematically with them" (Kruglikov, 1999: 22). Other researchers also write about the fact that the criminal law is closely connected with other branches of law, it exists and is realized only in the system of branches of law (Maltsev, 2000: 51).

The other theoretical model of inter-sectoral relations is based on the existence of functional relations that develop between the criminal and other branches of law. According to this view, each branch has its own inherent functions that it performs in the framework of the legal community. Obviously, in this case, the relations between branches develop into complex multifunctional connections, in which a change in one branch of legislation may cause a definite change in another.

It is believed that within the framework of inter-sectoral functional interaction, the criminal law is intended to perform the function of protection from possible criminal violations of the most important social relations regulated by other branches of law. In strict accordance with the functional approach, the criminal law is intended to protect not all the particularly significant social relations, but only a part of them that is regulated by other branches of law. In this regard, it is argued that certain social benefits and interests should only be protected by criminal law when they are a legal value, and social relations - when they become legal relations. Thus, N.F. Kuznetsova noted that "the interests (objects) protected by a criminal code are legal relations in various spheres of personal activity, the functioning of society and the state" (Borzenkova, Komissarova, 1997: 16). E.V. Voroshilin: "The specificity of the criminal law lies in the fact that it protects those social relations that are regulated by the norms of other branches of law from the most dangerous attacks." Hence the conclusion that it is inappropriate to adopt "new criminal law norms on issues that are not positively regulated by other branches of law" (Kudriavtsev, 1969: 160). Why? If social relations are not legally regulated, this may mean that they do not have that special value for society that requires their criminal law protection, and, therefore, there is no need to protect them. In addition, if the relations are not regulated by a particular branch of law, it is difficult to legally determine the exact object, subject composition and content of these relations and, therefore, it is impossible to ensure their reliable criminal law protection.

The functional relationship between branches creates a "general background" and sets the limits for the institutions and norms of the Special part of the criminal 
law, and, therefore, influences the content of the latter. In this regard, it is obvious that the functional relations that develop between criminal law and other branches of legislation significantly influence the definition of criminal illegality as a legal sign of a crime. Indeed, if criminal law is intended to protect relations already positively regulated by other sectors, then a criminal law prohibition (or prohibitions) should logically follow, it is necessary to flow out of a certain permission, and, therefore, to receive content compatible with the content of the latter. This is justified by the fact that in the conditions of the implementation of the law (i.e., the proper functioning of legal norms, institutions, branches and the entire legal system), certain criminal law prohibitions correspond to certain legal permits legally ensuring their effectiveness.

Thus, criminal wrongfulness is determined by the criminal law taking into account the actions of those legal permissions of various sectoral nature that positively regulate social relations violated by a criminal act. In this case, the permissions and the corresponding criminal law prohibitions must have equivalent content, i.e. to express the same legal position in different legal forms.

The criminal law is "entangled" by complex relations. This is due to a number of circumstances, some of which have already been addressed. Here, in view of the above, we will try to summarize the main factors that determine the effect of complex regularities in the criminal law.

Firstly, a comprehensive study of a number of the criminal law phenomena is determined by understanding of the criminal law as a complex holistic entity. The criminal law is a multidimensional and multilevel phenomenon - a branch of law, a branch of legislation, a branch of science, and an academic discipline. The subjects of protection of the criminal law are the most important social relations (part 1 of article 2 of the Criminal Code), the absolute majority of which are complex in nature. The method of the criminal law as a branch of law is a complex of legal means, including prohibitions, positive obligations, permissions and incentives. In the theory of the criminal law and legislation, an integrated approach has been developed to defining a crime, which can be conditionally called material and formal. The criminal law in the fight against crime uses a complex of coercive measures of a criminal law nature. R.R. Galiakbarov considers divisible (complex) crimes in the form of a single interconnected complex (Kruglikov, 1999: 311). The totality of crimes reflecting the combination of independent elements of crimes with their own sanctions also appears to be nothing more than a complex formation in the criminal law. As V.N. Kudriavtsev notes, the correct understanding of the complex nature of a number of crimes 
by practitioners of justice makes it possible to solve questions of the criminal acts corresponding to more than one definition more precisely and apply several articles of the criminal law only in really necessary cases (Kudriavtsev, 1999: 252).

Often, the combined action of several types of punishment ("complex" punishment) is required to achieve the goals of punishment, and if one of them is not used, then the goals of punishment cannot be achieved, or are not fully achieved. In connection with the above, cumulative sanctions are one of the legislative expressions of complexity in the criminal law.

Secondly, complexity in the criminal law finds expression in the special interrelation of the criminal law as a branch of law and legislation with other branches. Hence, the correct application of the criminal law is impossible without taking into account their complex interaction with the regulations of other branches. This is explained by the fact that often the norms of the criminal law and other sectoral nature act together, simultaneously regulate, and at the same time provide protection to the same relation. In this sense, they constitute a single integrated whole acting on the basis of the principles of various sectoral affiliations.

In conclusion, we emphasize that when discussing the significance of systematicity one should bear in mind the inadmissibility of its absolutization. Any means of the methodology has its limits. The possibilities of system thinking are also limited. First of all, it should be pointed out that the system approach has not acquired the form of a strict methodological concept; it performs its heuristic functions, remaining not very tightly connected by a set of cognitive principles orienting specific research towards a certain direction. According to V.M. Syrykh, "the theory of systems itself does not yet lead to the discovery of new sides and new aspects in specific sciences, in particular in jurisprudence... The use of this theory by lawyers did not entail a revolution in law, but only made it possible to clarify certain issues of legal science" (Syrykh, 2000: 457). The system research leads to certain "coarsening" of the object of knowledge and, accordingly, to the erasure of a number of interactions and relations that are characteristic of it and are very significant from the point of view of the particular sciences. For example, a system analysis of the criminal law is fraught with the "loss" of such factors affecting the legislative process as historical, cultural, national-traditional, political, socio-economic, etc. The systemic structure of the criminal law leads to the division of the criminal law into separate legal prescriptions and distribution of the latter in its structural parts; in order to establish a norm, every time it is necessary to mentally connect its structural components spread out according to the Criminal Code, which 
is often accompanied by errors in law enforcement. Finally, in the real world, with its countless number of interrelated phenomena, the degree of complexity of systemic education increases with a transition to a higher level. In this case, the relations between the components of the system become multi-valued, the manifestation of systemic laws becomes multi-variant, and the functioning of the system itself is chaotic. "The world is stochastic in nature," as N.N. Moiseev wrote. "There are fundamental uncertainties in it" (Moiseev, 1992: 64). The system approach loses its cognitive abilities with the movement of scientific research to more and more complex objects characterized by the multivariate nature of functioning and development. It cannot embrace the whole multitude of components and connections of such a total whole. From the point of view of criminal law-making, this means that at the level of interaction of criminal law with legal and other social systems, it is necessary to use other methodological means that contribute to the "alternate" vision of the evolution of Russian criminal legislation, taking into account its interaction with other branches and dependence on the socioeconomic and political development of modern society.

\section{References}

Afanas'ev, V.G. (1981). Obshchestvo: sistemnost', poznanie i upravlenie [Society: consistency, knowledge and management]. Moscow, Politicized, $432 \mathrm{p}$.

Alekseev, S.S. (1971). General theoretical principles of the study of the structure of law. In Soviet state and law Moscow, 3.

Blauberg, I.V., Iudin, E.G. (1973). Stanovlenie i sushchnost' sistemnogo podkhoda [Formation and essence of the system approach]. Moscow, Science, $274 \mathrm{p}$.

Borzenkova, G.N., Komissarova, V.S. (1997). Ugolovnoe pravo RF: Osobennaia chast': Uchebnik [Criminal law of the Russian Federation: Special part: Textbook]. Moscow, Olimp; “IZDATEL'stvo AST", 660 p.

Gercenzon, A.A. (1970). Ugolovnoe pravo $i$ sociologiia [Criminal law and sociology]. Moscow, The faculty of law.lit, $286 \mathrm{p}$.

Iavich, L.S. (1972). Obshchaia teoriia prava [General theory of law]. Leningrad, Publishing house of Leningrad University, $285 \mathrm{p}$.

Ignatov, A.N., Krasikov, Y.A. (1998). Ugolovnoe pravo Rossii: Uchebnik. V 2-h t. T. 1: Obshchaya chast' [Criminal law of Russia: Textbook. In 2 t. T. 1: the General part]. Moscow, Publishing group NORMA-INFRA, $639 \mathrm{p}$.

Kedrov, B.M. (1980). The modern classification of Sciences (the Main trends in its evolution). In question of philosophy, 10. 
Kerimov, D.A. (1972). Filosofskie problemy prava [Philosophical problems of law]. Moscow, thought, $472 \mathrm{p}$.

Kliland, D., King, V. (1974). Sistemnyi analiz i tselevoe upravlenie [System analysis and target management]. Moscow, Soviet radio, $120 \mathrm{p}$.

Kliland, D., King, V. (1974). Sistemnyi analiz i tselevoe upravlenie [Systems analysis and target management]. Moscow, Soviet radio, $280 \mathrm{p}$.

Kozlov, V.A. (1989). Problemy predmeta i metodologii obshchei teorii prava [Problems of the subject and methodology of the General theory of law]. Leningrad, $120 \mathrm{p}$.

Kruglikov, L.L. (1999). Ugolovnoe pravo Rossii: Chast' Obshchaia: Uchebnik [Criminal law of Russia: General Part: the Textbook]. Moscow, BEC publishing house, $592 \mathrm{p}$.

Kudriavtsev, V.N. (1999). Obshchaia teoriia kvalifikatsii prestuplenii [General theory of qualification of crimes]. Moscow, lawyer, 304 p.

Kudryavtsev, V.N. (1969). Two books on criminal law. In Soviet state and law, 10.

Kuzmin, V.P. (1980). The principle of consistency in the methodology of dialectical and historical materialism. In question of philosophy, 2.

Maltsev, V.V. (2000). Concept and place of criminal law in the system of branches of law. In State and law, 5.

Moiseev, N.N. (1992). Puti k sozidaniiu [The way to creation]. Moscow, Republic, 255.

Osipov, P.P. (1989). Kompleksnoe izuchenie sistemy vozdeistviia na prestupnost'. Metodologicheskie i teoreticheskie osnovy [A comprehensive study of the system of impact on crime. Methodological and theoretical basis]. Leningrad, $120 \mathrm{p}$.

Pavlov, I.P. (1952). Poln. sobr. soch. V VI-ti t. Izd. 2-e i dop. M.-L.: T. V. Lekcii po fiziologii [Pavlov, I. P. Poln. Coll. Op. In VI t Ed. 2-e and additional: T. V. Lectures on physiology]. Moscow, publishing House of the USSR Academy of Sciences, $435 \mathrm{p}$.

Polevoi, N.S. (1993). Pravovaia informatika i kibernetika: Uchebnik [Legal Informatics and Cybernetics: Textbook]. Moscow, legal literature, 528 p.

Ponyatovskaya, T.G. (1994). Kontseptual'nye osnovy ugolovnogo prava Rossii: istoriia i sovremennost' [Conceptual framework of the criminal law of Russia: history and modernity]. Izhevsk, Udmurt state University, 140 p.

Spiridonov, L.I. (1986). Sociologiia ugolovnogo prava [Sociology of criminal law]. Moscow, legal literature, $240 \mathrm{p}$.

Stefanov, N., Simenova, K., Kostov, K., Kachaunov, S. (1975). Programmnotselevoi podkhod $v$ upravlenii. Teoriia $i$ praktika [Program-target approach in management. Theory and practice]. Moscow, legal literature, $240 \mathrm{p}$. 
Syrykh, V.M. (2000). Logicheskie osnovaniia obshchei teorii prava: $V 2$ t. T. 1 Ehlementnyj sostav [Logical foundations of the general theory of law: In 2 t. T. 1 Ehlementnyj sostav]. Moscow, Justicinform, 528.

Tarasov, N.N. (1971). Method and methodological approach in jurisprudence (attempt of problem analysis). In jurisprudence, 1.

Tarasov, N.N. (2001). Method and methodological approach in law (attempt problem analysis). In Jurisprudence, 1.

Tenenbaum, V.O. (1971). Gosudarstvo: sistema kategorii [State: system of categories]. Saratov, publishing house of Saratov University, 212 p.

Tikhomirov, Iu.A., Khabriev, T.Ia. (2014). Kontseptsii razvitiia rossiiskogo zakonodatel'stva [Concepts of development of the Russian legislation]. Moscow, SISP, $128 \mathrm{p}$.

Vasil'ev, A.M. (1976). Pravovye kategorii. Metodologicheskie aspekty razrabotki sistemy kategorii teorii prava [Legal category. Methodological aspects of the development of the system of categories of the theory of law]. Moscow, The faculty of law. lit, $264 \mathrm{p}$.

Vitushko, V.A. (2000). Complex-individual method in civil law and law enforcement practice. In State and law, 9.

\title{
Системность уголовного законодательства России: вопросы методологии
}

\author{
А.Г. Безверхов, Ю.С. Норвартян \\ Самарский национальный исследовательский \\ университет имени академика С.П. Королева \\ Россия, 443086, Самара, Московское шоссе, 34
}

В настоящей статье исследуются возможности и предель использования системного подхода в уголовно-правовой материи, его соотношение с другим методологическим инструментарием. Показано, что системное строение уголовного законодательства России имеет своим назначением упорядочение правового материала, обеспечение его непротиворечивости и полноты регулирования общественных отношений, исключение в уголовном законе дублирования и пробелов. Установлено, что системность - явление как внутриотраслевое, так и межотраслевое. Уголовное право системно связано со многими другими отраслями: конституционным, гражданским, трудовым, финансовым, экологическим правом; уголовно-исполнительным, процессуальным и пр. При этом уголовная противоправность определяется уголовным законом с учетом действия тех юридических предписаний различной отраслевой 
природы, которые регулируют общественные отношения, нарушаемые преступным деянием.

Ключевые слова: системный подход, систематика, системные связи, система уголовного права, система уголовного законодательства, систематическое толкование, Общчая и Особенная части уголовного права.

Научная специальность: 12.00.00 - юридические науки. 